\title{
Assessment of Forest Investment, Financial Flows and Revenue Collection in the Abia State Forest Sector, Nigeria
}

\author{
${ }^{1}$ EGU, EC; ${ }^{1 *}$ NWANKWO, EC; ${ }^{2}$ OFFIONG, EE
}

\author{
${ }^{1}$ Department of Forestry and Environmental Management, Michael Okpara University of Agriculture, Umudike, Nigeria \\ ${ }^{2}$ Department of Forestry and Wildlife Resources Management, University of Calabar, Nigeria \\ ${ }^{*}$ Corresponding Author Email: nwankwo.emmanuel@mouau.edu.ng
}

\begin{abstract}
Varieties of resources abound in the forests of Nigeria and especially in Abia state, an economic treasure house of resources. Sustainable management of the forests in Nigeria is crucial for a consistent supply of forest resources. Ten forest reserves were surveyed to determine the extent of the government's involvement in sustainable forest management in Abia State. The government consider the forest reserves, as a revenue-generating venture, leading to the excessive exploitation of forest resources in the state. The exploitation is without regard for sustainability as the harvest is consistently higher than its growth. The government's involvement in funding the forestry sector over these years has been the payment of salaries to staff of the State forestry department and revenue collection, while international donors, corporate organizations and private sectors have not considerably invested in the Abia State forest sector. The survey revealed the challenges militating the productivity of the forest sector in Abia State, namely: inadequate capital, administrative incompetence and bureaucratic bottleneck, political instability, ecological challenge, insufficient skilled personnel, corruption, lack of forest equipment and inefficient forest laws. Training should be organized for the forest staff and communities to ensure the sustainable use of forest resources. There is a need for the modernization of forestry practice in Abia State and all that go with it being accorded a well-deserved priority in the present economic dispensation in Nigeria.
\end{abstract}

\section{DOI: https://dx.doi.org/10.4314/jasem.v25i5.11}

Copyright: Copyright (C) 2021 Egu et al. This is an open access article distributed under the Creative Commons Attribution License (CCL), which permits unrestricted use, distribution, and reproduction in any medium, provided the original work is properly cited.

Dates: Received: 20 March 2021; Revised: 27 April 2021; Accepted: 07 May 2021

Keywords: forest investment, forest economics, revenue collection, sustainable management

Investment and finance are critical components of successful economic development. Generating the appropriate levels of capital is already a difficult undertaking when aiming to meet specific social and economic needs, but generating and allocating the investment and financial flows needed to meet the Millennium Development Goals (MDGs) and indeed the Sustainable Development Goals (SDGs). To finance significant climate change mitigation through investment in forest plantations will make this task all that much harder (UNFCCC, 2008). Varieties of resources abound in the forests of Nigeria and especially in Abia State and they include soil and its mineral deposits, water sources, rock, outcrops, rare landscapes and, in the biological sense, plant and animals in all their various forms. The forest is, therefore, an economic treasure house of resources and if properly managed Nigeria's forests can supply its people's needs in perpetuity (Nelson and Jacob, 2017). The forest as an organic entity is a store-house of innumerable benefits (Etukudo et al., 1994). It plays a variety of vital roles in rural development through: provision of food and fodder, medicine, fuelwood, wood working, timber, game and wildlife, raw materials for industries and employment. Nigerian forests are a profusion of wide and edible food complexes-fruits, roots, green leafy vegetables, spices and mushrooms for human and animal consumption. Okafor (1980) has identified 150 species of indigenous woody plants with edible fruits of high nutritive values. Amongst the several indigenous trees and woody plants that are extensively cultivated for edible fruits of importance to man include coconut (Cocos nucifera), African bread fruit (Treculia africana), oil bean tree (Pentaclethra macrophylla), mango (Mangifera indica), oranges (citrus), oil palm (Elaeis guinensis), etc. The fruits of some of these tree plants are processed as soft drinks, examples are mango and orange juices. The oil extracted from the oil palm is used in the manufacture of soap, cooking oil and margarine. The important beverages obtained from some forest trees include, cocoa (Theobroma cocoa) which is the source of cocoa and chocolate, coffee (various species of coffee) and tea (Camellia sinensis). Global attention to climate change has heightened awareness of human impacts on the environment. Progressing more slowly in this respect is recognition of the crucial inter-relatedness of forests, forest

*Corresponding Author Email: nwankwo.emmanuel@mouau.edu.ng 
investment and financial flows (UNFCCC, 2008). Forests are a key component of environmental resources as they provide a rich assortment of products such as timber and ecosystem services that include the sheltering of agricultural crops against drought, sustaining watersheds, maintaining water purification, protecting humankind against nuisances (fumes, noises, smells, storms), flood regulation, recreational opportunities, spiritual and cultural fulfillment and more importantly, climate change, as both a cause and a solution (Browns et al., 2000). Risks associated with inefficient allocation of resources may impede the effective flow of forest finances and present opportunities for misappropriation or contribute to misrepresentation of financial flows. Such inefficiencies may result from poor organisational structures, high transaction costs, overlaps and gaps in funding, stagnant funds, over-allocation, poor quality of information for policy-making and inadequate human resources. Drawing from the information gathered through interviews, a number of forest management options and approach adopted by the Abia State government in managing State forest reserves presents the need and pathway to potential investment and studies on financial flows. Abia State has 19 forest reserves. The forests have been excessively exploited over the years without significantly enhancing their growth, structure, stock and species density. The exploitation is without regard for sustainability as harvest was consistently very much higher than its growth (ABSEEDS, 2005). However, previous and current state governments have repeatedly stated their contributions to the development of the forestry sector. The level of their involvement in the said funding and contributions to forestry sector development through fiscal appropriations and annual budgets are not known and largely superficial. Furthermore, Information on private investment by institutional investors, commercial banks and export credit agencies is not available and neither is it known how much the NGO and philanthropy sector contributes to forest financing. On the other hand, it is believed that Abia State forestry sector receives assistance either through grant or loan from other institutions (foreign and/or local), bodies, NGOs, development partners and even individuals. Also, capital cost of new physical asset as a result of investment flow is relatively unknown. This information is still speculative as no journal has reported it. The main objective of this study was to assess the performance of investment and financial flows, over the period of 10 years with a view to determine their contribution to development of Abia State forest sector. Specifically to: determine the level of state government's involvement through its expenditure in the forest sector during the specified period, identify funding sources and investments flows in Abia State forest sector, identify the main sources of revenue and modes of collection, assess the trend of forest revenue collection within the specified period and the share of revenue that is dedicated to forest development, and identify the problems militating against.

\section{MATERIALS AND METHODS}

Study Area: The study on the assessment of forest investment, financial flows and revenue collection was carried out in the Abia State forest sector. Abia State of Nigeria, with Umuahia as Capital was created on $27^{\text {th }}$ August, 1991 out of the old Imo State. It is one of the five states in the Southeast geo-political zone of Nigeria (Figure 1). Abia State lies between longitude $04^{\circ} 45^{\prime}$ and $06^{\circ} 17^{\prime}$ North, and latitude $07^{\circ} 00^{\prime}$ and $08^{\circ} 10^{\prime}$ East

The State is located east of Imo State and shares common boundaries with Anambra, Enugu and Ebonyi States to the North West, North and North East respectively. To the East and South East, it is bounded by Cross River and Akwa lbom States and by Rivers State to the South. It occupies a landmass of 5,833.77 square kilometers. The State is about 596 kilometers from Lagos and about 498 kilometers from Abuja. The State is located within the forest belt of Nigeria, and the temperature ranges between $20^{\circ} \mathrm{C}$ and $36^{\circ} \mathrm{C}$. It is characterized by the dry dust-laden Northeasterly winds, which blows across the country during the dry season (mid-October to March). The rainy period is from April to October, during which period the moisture-laden Southwesterly winds blow, bringing with it the rains

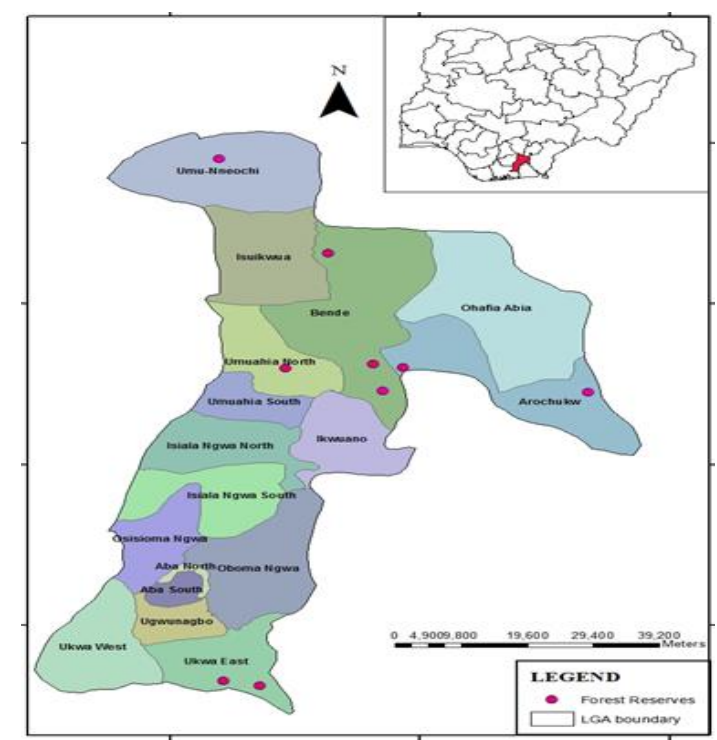

Fig 1 Map of Abia State showing Forest Reserves in various Local Governments 
Study Design: This study was carried out in five forest administrative zones in Abia State namely Ukwa, Isikwuato, Arochukwu, Bende and Umuahia (Administrative headquarters) with the exception of Aba zone which has no forest reserve. Purposive sampling was used to select these forest administrative zones since one of the zones has no forest reserve. A total of one hundred and fifty copies of questionnaire were administered to all the stakeholders in these zones and officials of the forestry sector. Purposive sampling was also used to collect the primary data. The respondents were stratified into four categories of zonal class. Category A comprising forestry staff of Arochukwu zone, the enclaves and the timber contractors. Category B comprises forestry staff of Bende zone, the enclaves and the timber contractors. Category C comprises forestry staff of Isikwuato zone, the enclaves and the timber contractors. Category D comprises forestry staff Ukwa zone, the enclaves and the timber contractors. Category E comprises forestry staff of Umuahia zone, the enclaves and the timber contractors. Category F comprises Federal Department of Forestry (FDF), Forestry Research Institute of Nigeria (FRIN) and The Department of Forestry and Environmental Management, Micheal Okpara University of Agriculture Umudike. Twenty five copies of questionnaires were administered randomly to each category of zonal class following Diaw et al (2002), which states that a minimum of $10 \%$ sampling intensity could serve as a representative figure for a population less than 500 people. The total staff strength of Abia State forestry sector as at the time of this assessment was 50. The total staff strength of Federal Department of Forestry at the time of this assessment was 5, while that of FRIN was 52.

Data Collection: Data on forest revenue from the five administrative zones of the Abia State forest sector and the expenditure for the period under study were obtained from the Department of Forestry, State Ministry of Environment, Abia State. The study also incorporated interviews and focused discussions with the forestry department officials. Other supplementary information were sourced from relevant literature such as Forest journals, textbooks, technical and annual reports.

Data Analysis: his study examined the performance of investment and financial flows in the Abia State forest sector, therefore we need to access whether the targets of the objectives were met. Data obtained were integrated into each of the various components under study and descriptive statistics (that is frequencies and percentages, line graphs).
Percentage Annual Change Computation: The percentage annual change method was used according to Leuschner (1984) to obtain the average percentage in revenue. Simple percentage formula was also used to obtain the yearly percentage changes in revenue for the period under review.

Percentage annual change procedure is given as: $C=\left\{(Y b \div Y a)^{\frac{1}{c}}-1\right\} \ldots \ldots 1$

Where $\mathrm{C}=$ percentage annual change; $\mathrm{Yb}=$ value in base year (2014): Ya = value in first year (2005)

$c=b-a$

Simple percentage procedure is given as:

$S=\{Y a-(Y b) / Y b \quad \ldots \ldots 2$

Where $\mathrm{S}=$ Yearly percentage decrease; $\mathrm{Yn}=$ value in current year; $\mathrm{Yb}=$ value in base year

\section{RESULTS AND DISCUSSION}

Investment and project financing is an essential and integral factor in determining the success of development in any economy. However, forest resources in Abia State have continued to yield considerable varying revenue to the Abia State government.

Awareness of government funding in the Abia State forest sector: Among twenty five (25) respondents (staff, forest enclaves and the timber contractors) sampled in each of the administrative zones of the Abia State forestry sector, very small percentage of respondents admit their knowledge of government involvement in funding the forest sector (Table 1). In Isiukwuato zone which has two forest reserves (Umuelem and Ovim), only $20 \%$ of the respondents admitted their knowledge of government funding of the forestry sector and forest reserve improvement, while $80 \%$ reports no sign of government funding the forestry sector. In Arochukwu zone which has two forest reserves (Achara Ihe and Ndi Okpo), 2\% of the respondents accepted their knowledge of government funding to the forestry sector, while $88 \%$ said they had no knowledge of government funding of the forest sector. Cumulatively, $62.7 \%$ of the respondents are not aware of the government funding of the forest sector, while $37.3 \%$ said they were aware. Of the 134 respondents sampled, $76.11 \%$ reported that the mode of funding of the forest sector by the government was done annually, $10.4 \%$ agreed that the funding was done periodically, $8 \%$ reported monthly, $4.5 \%$ 
admitted it was done quarterly, while $0.7 \%$ stated biannually in funding the forest sector.

Table 1. Knowledge of Government Involvement in Funding the

\begin{tabular}{|c|c|c|c|}
\hline \multicolumn{4}{|c|}{ Forest Sector in Abia State } \\
\hline Zone & Responses & Frequency & Percentage \\
\hline \multirow[t]{3}{*}{ Isiukuato } & Yes & 5 & 20.0 \\
\hline & No & 20 & 80.0 \\
\hline & Total & 25 & 100.0 \\
\hline \multirow[t]{3}{*}{ Arochukwu } & Yes & 3 & 2.0 \\
\hline & No & 22 & 88.0 \\
\hline & Total & 25 & 100.0 \\
\hline \multirow[t]{3}{*}{ Bende } & Yes & 10 & 40.0 \\
\hline & No & 15 & 60.0 \\
\hline & Total & 25 & 100.0 \\
\hline \multirow[t]{3}{*}{ Umuahia } & Yes & 13 & 52.0 \\
\hline & No & 11 & 44.0 \\
\hline & Total & 24 & 96.0 \\
\hline \multirow[t]{4}{*}{ Ukwa } & Yes & 14 & 56.0 \\
\hline & No & 10 & 40.0 \\
\hline & 7 & 1 & 4.0 \\
\hline & Total & 25 & 100.0 \\
\hline \multirow[t]{3}{*}{ FRIN } & Yes & 2 & 42.9 \\
\hline & No & 4 & 57.1 \\
\hline & Total & 7 & 100.0 \\
\hline MOUAU & Yes & 2 & 100.0 \\
\hline
\end{tabular}

Among the 134 respondents sampled, $84.9 \%$ indicated that government funded forestry projects through annual budget for the specified base year, $10.9 \%$ admitted funding through subvention/subsidy, 1.7\% admitted funding through Foreign Direct Investment (FDI), while $0.8 \%$ of respondents agreed that funding of forest sector was done through Official Development Assistance (ODA) and donor agencies for the years under in review. Abia State government was identified by the respondents as the major source of funding to the forestry department in the state, followed by federal government allocation (Figure 2). The study also revealed that the forest sector has not received any fund from the Local government in any form though forest reserves are situated in these Local Government areas.

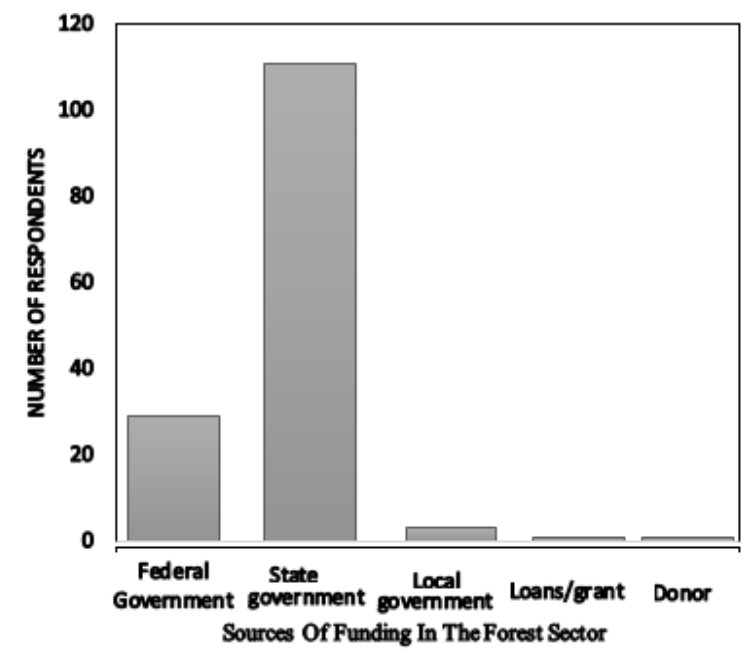

Fig 2. Sources of Fund to the Abia State Forest Sector

Investments in the Abia State Forest Sector: The State government between 2005-2014 through budgetary provision and the Federal Government through grants have invested in sustainable forest management in establishing Special Teak Project (Ukpom and Ubibio Forest Reserves) and Gmelina and Treculia africana plantations in (Ubeaku and Ohambele Forest Reserves) (Table 2). Information from the officials of the forestry department reveals that the investments were a failure largely due to to administrative incompetence and corruption. There was no meaningful investment in Sustainable Forest Management in the ten forest reserves (Umuelem, Ovim, Achara Ihe, Ndi Okpo, Ubibio, Umuahia Ibeku, Nkalunta, Ubeaku, and Ohambele) in Abia state from 2005 to 2014.

Table 2. Major Investments/ donor in the Forestry Sector in Abia State 2005-2014

\begin{tabular}{|c|c|c|c|c|c|}
\hline $\begin{array}{l}\text { Funding } \\
\text { Agency }\end{array}$ & $\begin{array}{l}\text { Amount } \\
\text { Invested }\end{array}$ & $\begin{array}{l}\text { Period } \\
\text { Covered }\end{array}$ & Investment Area & $\begin{array}{l}\text { Type of } \\
\text { Assistance }\end{array}$ & $\begin{array}{l}\text { Forest } \\
\text { Reserve }\end{array}$ \\
\hline $\begin{array}{l}\text { Abia State } \\
\text { Government }\end{array}$ & $\begin{array}{l}\text { Not } \\
\text { available }\end{array}$ & $\begin{array}{l}2008- \\
2009\end{array}$ & $\begin{array}{l}\text { Sustainable Forest } \\
\text { Management (Special Teak } \\
\text { Project) }\end{array}$ & $\begin{array}{l}\text { Budgetary } \\
\text { provision }\end{array}$ & $\begin{array}{l}\text { Ukpom and } \\
\text { Ubibio FR }\end{array}$ \\
\hline $\begin{array}{l}\text { Federal } \\
\text { Government } \\
\text { and the } \\
\text { World Bank }\end{array}$ & $\begin{array}{l}\text { Not } \\
\text { available }\end{array}$ & $\begin{array}{l}2012- \\
2013\end{array}$ & $\begin{array}{l}\text { Sustainable forest } \\
\text { management (raising of two } \\
\text { hundred thousand seedling of } \\
\text { Teak, Gmelina arborea, } \\
\text { Treculia africana) }\end{array}$ & Grant & $\begin{array}{l}\text { Ubeaku and } \\
\text { Ohambele } \\
\text { FR }\end{array}$ \\
\hline
\end{tabular}

Under nursery establishment, no investment was made in all the forest reserves from 2005 to 2014 as indicated by the respondents. The $49.3 \%$ of respondents that responded "yes" to investment in nursery establishment could not differentiate between government and private owned nursery business. Also, the $49.3 \%$ percent recorded was due to the two million seedling project funded by the Federal Government and the World Bank between 2012-2013. However, the seedlings overgrew and no money was released for transplanting activities (Table 2). Furthermore, there was no investment in capacity building (training and 
re-training) of staff of the Abia State forestry sector from 2005 to 2014. Also, under value-added processing to make timber extraction more efficient by reducing wastage, no investment was made under the year in review. $61.9 \%$ of the respondents said such has not been witnessed. Only $6 \%$ responded "yes", while the rest of the respondents did not respond to the question.

Sources of Revenue and the Models of Collection: In Abia State, timber, industry and enterprise, non-wood and minor forest product, hunting and recreational forest land-used fees constitute the major sources of revenue based on 24 models of assessing resources (Table 3). The models are: Value Based Charge Or Stumpage Valuation, Unit Area Charge, Out-Turn
Volume (OTV), Timber Landing Fees, Fees For Logging, Registration Fees For Holders Of Property Hammer, Registration Fees For Timber Contractors, Registration For Power Saw, Registration For Table Saw, Fees For Collection Of Leaves, Fees For Collection Of Indigenous Fruit Trees, Fees For Tapping Wine, Fees For Collection Of Fuelwood, Fees For Carrying Out Agricultural Activities In The Reserve, Fees For Collection Of Chewing Sticks, Hunting Permit Fees, Permits To Reside In The Forest, Fees For Illegal Possession Of Timber, Fees For Illegal Farming Within Forest Reserves, Fees For Illegal Possession Of Fuelwood From Forest Reserves, Fees For Illegal Excavation Within The Reserves, Fees For Illegal Logging, Fines, Fees For Conservation Offences.

Table 3. Main sources of forest revenue and models of collecting them in Abia State

\begin{tabular}{|c|c|c|}
\hline $\begin{array}{l}\text { Revenue } \\
\text { sources }\end{array}$ & Models of collection & Remark \\
\hline \multirow{5}{*}{$\begin{array}{l}\text { Timber } \\
\text { extraction } \\
\text { fees }\end{array}$} & Value based charge or stumpage valuation & * \\
\hline & Unit area charge & $*$ \\
\hline & Out-turn volume (OTV) & $*$ \\
\hline & Timber landing fees & $*$ \\
\hline & Fees for logging & * \\
\hline \multirow{4}{*}{$\begin{array}{l}\text { Industry } \\
\text { and } \\
\text { enterprise } \\
\text { fees }\end{array}$} & Registration fees for holders of property hammer & $*$ \\
\hline & Registration fees for timber contractors & $*$ \\
\hline & Registration for power saw & $*$ \\
\hline & Registration for table saw & $*$ \\
\hline \multirow{6}{*}{$\begin{array}{l}\text { Non wood } \\
\text { and minor } \\
\text { forest } \\
\text { product fees }\end{array}$} & Fees for collection of leaves & $*$ \\
\hline & Fees for collection of indigenous fruit trees & $*$ \\
\hline & Fees for tapping wine & $*$ \\
\hline & Fees for collection of fuelwood & * \\
\hline & Fees for carrying out agricultural activities in the reserve & $*$ \\
\hline & Fees for collection of chewing sticks & $*$ \\
\hline \multirow[b]{2}{*}{$\begin{array}{l}\text { Hunting } \\
\text { and } \\
\text { recreational } \\
\text { forest land- } \\
\text { use fees }\end{array}$} & Hunting permit fees & $*$ \\
\hline & Permits to reside in the forest & * \\
\hline \multirow{5}{*}{$\begin{array}{l}\text { Penalties for } \\
\text { breaking } \\
\text { forest laws }\end{array}$} & Fees for illegal possession of timber & $*$ \\
\hline & Fees for illegal farming within forest reserves & $*$ \\
\hline & $\begin{array}{l}\text { Fees for illegal possession of fuelwood from forest } \\
\text { reserves }\end{array}$ & $*$ \\
\hline & Fees for illegal excavation within the reserves & $*$ \\
\hline & Fees for illegal logging & $*$ \\
\hline \multirow[t]{2}{*}{ Legal fees } & Fines & $*$ \\
\hline & Fees for conservation offences & $*$ \\
\hline
\end{tabular}

Table 4. Trend in Revenue Generation, Percentage yearly changes, Percentage Decrease and in Actual Revenue over Estimated revenue in

\begin{tabular}{lllll}
\multicolumn{5}{c}{ the Abia State Forest Sector } \\
\hline $\begin{array}{l}\text { Financial } \\
\text { year }\end{array}$ & $\begin{array}{l}\text { Estimated } \\
\text { revenue }(\mathbb{N})\end{array}$ & $\begin{array}{l}\text { Actual revenue } \\
(\mathbb{N})\end{array}$ & $\begin{array}{l}\% \\
\text { Decrease }\end{array}$ & $\begin{array}{l}\text { Annual } \\
\text { increase }(\%)\end{array}$ \\
\hline 2005 & 500,000 & 406,770 & 18.6 & \\
2006 & 700,000 & 402,900 & 42.4 & -0.95 \\
2007 & $1,000,000$ & 716,570 & 28.3 & 77.85 \\
2008 & $1,000,000$ & 684,900 & 31.5 & -4.42 \\
2009 & $1,200,000$ & 769,300 & 35.2 & 12.32 \\
2010 & $1,500,000$ & 529,450 & 64.7 & -31.18 \\
2011 & $1,000,000$ & 751,630 & 24.8 & 41.96 \\
2012 & $2,000,000$ & $1,040,850$ & 47.9 & 38.48 \\
2013 & $2,000,000$ & 640,300 & 67.9 & -38.48 \\
2041 & $1,500,000$ & 766,700 & 48.8 & 19.74 \\
\hline
\end{tabular}


Among the sources of revenue in the Abia State forest sector, $100 \%$ of the respondents admitted that timber was the highest source of revenue to the forest sector, followed by penalties for breaking forest laws which has $96.2 \%$. However, $87.7 \%$ of the respondents agreed that non-wood and minor forest product is also a major source of forest revenue while $39.3 \%$ said industry and enterprise is a revenue generation source. The low percentage recorded in industry and enterprise is as a reflection of very few wood based industries in Abia State. Forest revenue collection officers are located in all the local government areas that were sampled and the state forest office. Revenue staff are also stationed at the entrances into the reserves, forest enclaves and at road check points. Forest revenue staff are not stationed in sawmills and timber sheds but can visit to collect revenue. Based on the responses from the survey, there is no visit of Ministry of Environment revenue officers to zones. Also, there has never been training of revenue staff or training organized for the purpose of effective forest revenue generation nor any available welfare package for the forest revenue collectors from 2005 to 2014 . Furthermore, there is also the absence of vehicle to ease revenue collection task within the years under review. However, there were regular audit of field account, functional office for revenue unit in the headquarters (State Ministry of Environment) and also frequent meetings on revenue collection. The entire revenue assumed a decreasing trend from 2005 to 2006, but increased between 2006 and 2007 (Table 4). However, the revenue trend went downward from 2007 to 2008 and increased again in 2009. From 2010 to 2012, the revenue followed an increasing trend from $\$ 751,630$ to approximately N1.1 million, but decreased again in 2013. Furthermore, the revenue increased again between 2013 to 2014 by $\$ 126,400$. The rapid increase in revenue recorded in 2012 may be as a result of $100 \%$ increase in estimated revenue from $\$ 1$ million to $\$ 2$ million. Furthermore, the percentage of yearly changes in revenue generation in the Abia State forestry sector followed an inconsistent trend with the highest percentage decrease of $77.85 \%$ between 2006 and 2007 and the lowest decrease of $-0.95 \%$ between 2005 and 2006 (Table 4). Bende administrative zone generated the highest revenue compared to other administrative zones (Figure 3 ). The highest revenue from Bende was in 2012 which is to the tune of $\$ 511,350$. Next to Bende zone in revenue generation is Umuahia administrative zone followed by Arochukwu administrative zone but least in Isiukwuato administrative zone (Figure 4). Among all five factors used in determining location of a revenue staff (ability to oversee and monitor staff activities, cost, effectiveness/efficiency of control, availability of other resources, availability of skilled staff), majority of the respondents reported that the ability to oversee and monitor staff activities is the major factor. Though forest guards are the revenue collectors, the ability to oversee and monitor staff activities is a criterion for posting a staff (forest guard) to a reserve.

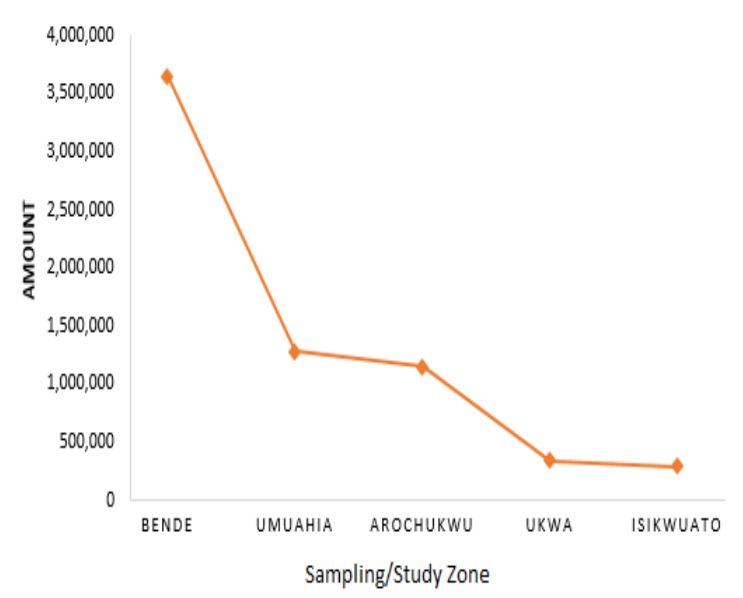

Fig 3 Total Revenue Trend among the Administrative Zones of the Abia State Forest Sector between 2005 and 2015.

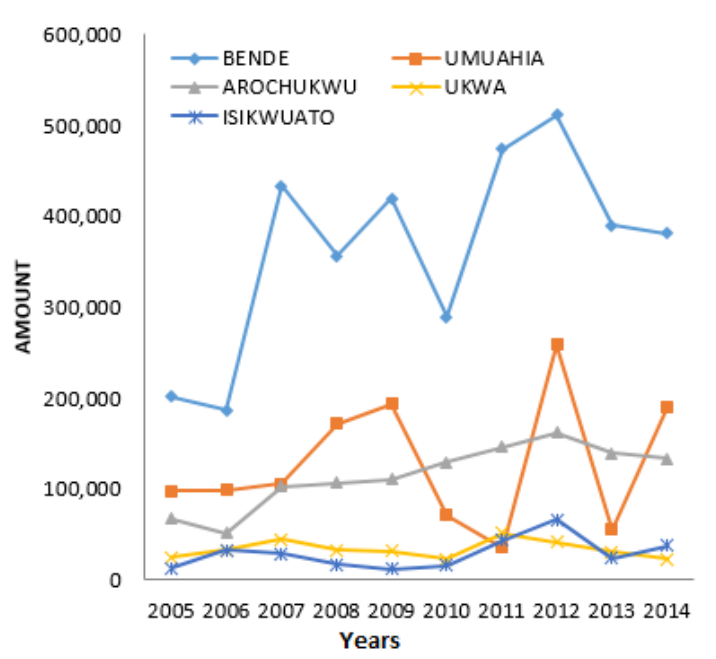

Fig 4: Yearly Actual Revenue Trend in the Administrative Zone of the Abia State Forest Sector

Problems Militating Against Forest Investment in the Abia State Forestry Sector: From the survey conducted, some of the problems militating against forest investment in the Abia State Forest sector were identified to include inadequate capital, administrative incompetence and bureaucratic bottleneck, political instability, ecological challenge, inadequate skilled personnel, corruption, ignorance of forest economics, lack of forest equipment and obsolete forest laws. Almost $90 \%$ of the respondents in all the forest administrative zones agreed that inadequate capital, administrative incompetence and bureaucratic bottleneck are major factors militating against forest 
investment. Between 50\%-60\% of the respondents said political instability, ecological challenge and inadequate skilled personnel is the problem militating against forest investment in the State. Between 10\% $20 \%$ of the respondents said corruption, ignorance of forest economics, no equipment and obsolete forest laws are problems militating against forest investment. It was also observed in the course of the study that political instability in some administrative zones, coupled with resentment and clash between the government and the local community over the control of their forest resources has also discouraged investment. Majority of the respondents reported that ecological challenges are militating against forest investment as the cost implication for afforestation in such an areas would be exorbitant. Low percentage $(14.3 \%)$ on inadequate skilled personnel was recorded in Forestry Research Institute of Nigeria (FRIN) compared to other zones. This may be attributed to the fact that the institute is made up of researchers and scientist both as contract, permanent or ad hoc staff.

Funding of forestry development in Nigeria is basically done by State governments. This relies entirely on annual allocations from government. The state governments, including Abia State, allocate funds each year to cover salary and wages as well as other operational costs (FAO, 2001). According to established forest laws, forests are under the custody of the State governments, but the state governments have been unable to meet their financial requirements for forestry development due to the low level of funding. This contrasts to earlier years, when states were able to cope because of assistance from foreign or external loans. Examples of such assistance include: the World Bank Forestry II Project; African Development Bank forestry development programmes; and the EEC/FGN Katsina Afforestation Project. Most of this assistance has either terminated or is about to terminate (FAO, 2001). Two fundamental issues for financing forest preservation are time and scale. Time is a concern because the longer we wait the more forest we lose. This increases greenhouse gas emissions and biodiversity loss while degrading the livelihoods of forest dependent communities and reducing the provision of other ecosystem services, vital on local to global scales. All of these effects reduce the resilience of forests and the broader economic and ecological systems that depend on them, increasing the risk of irreversible forest loss and long-term damage to the global economy (Cranford et al., 2011). Abia State government commitment to funding of forestry development is highly insignificant based on the findings of this study. Funding forestry development should involve project development, evaluation and monitoring. This should also have the capacity to create employment to the forest enclaves. The staff of the Abia State forest sector, the enclaves and the timber contractors of ten forest reserves in five forest administrative zones affirmed that they are not aware of any investment in forestry sector suggesting that no activities took place in those reserves other than timber exploitation (Table 1). Since 1970, technical assistance has been received on a number of occasions, with the aim of assisting Nigeria to increase its forest estate and manage the environment in a more sustainable way. Some of these assistance projects were done by organizations like FAO and UNDP between 1974 and 1976, World Bank between 1980 and 1984. However, for the period under review, there was no Foreign Direct Investment (FDI) in the Abia State forest sector. Also, no Official Development Assistance (ODA) or philanthropist/ donors assisted the state government in forest development from 2005 to 2014. Projects with costs and revenues that continue for more than one accounting period are referred to as investments. Parameters which were assessed in this study include sustainable management, nursery establishment, training of staff and value-added processing to make timber extraction efficient. The study revealed that from 2005 to 2014, no meaningful investment was made under sustainable forest management in ten forest reserves studied. Sustainable forest management has elements which include community forest, apiculture, ecotourism, forest fire management, improving degraded forest and investment in mangroves. Based on the data from the survey, there was no investment in sustainable forest management in Abia State. The result is opposite to the result of investment flow in sustainable forest management of the Gambian forest sector conducted in 2012, where the Gambian government provisions from government budget and allocation were in the tune of GMD $1,965,590$. There were very high expectations that funds would be available from Global Environment Fund (GEF 5 Star) to the tune of US\$2.00 million. (Rosendal and Andresen, 2011). However, no investment and financial flow chart on sustainable forest management was available in the Abia State forestry department. Under nursery establishment in the Abia State forest sector, there was no investment from 2005-2014. The reports on investment in nursery establishment were unable to differentiate between private owned nursery and government owned nursery enterprise. Between 20082009, a project tagged "Special Teak Project was initiated by the state government and equipment were bought for the project. However, the politics in Abia State as of then could not allow the project to see the light of the day without the cost of the project being captured. This correlates with the findings of the UNDP (2012), on the cost of investment in 
Participatory Integrated Watershed Management Project (PIWAMP) not being captured in Gambia. Similarly, between 2012-2013, the Federal government of Nigeria in conjunction with World Bank funded a project to raise two million seedlings of Teak, Gmelina arborea and Treculia aficana for Ubeaku and Ohambele forest reserves. The seedlings were raised but funds for transplanting exercise were not released which eventually killed the project. Under capacity building, no staff training took place from 2005-2014, and no investment took place from 2005 to 2014 on value-added processing to make timber extraction efficient by reducing wastage. After series of attempts in the quest for data and available expenditures on forest investment, the assessment was finally conducted without data available on government forest expenditures. There is also an acute shortage of information on government expenditures on forestry activities from 2005-2014. Abia State has nineteen (19) forest reserves, out of which ten (10) are functional. The non-functional ones are due to government laissez-faire attitude in forest management. Forest reserves are situated far from the forestry department of the ministry of environment. Forestry department offices are also situated in different local government areas of the state. At least two forest reserves are located in all the five forest administrative zones of the forestry department except Aba zone that has no reserve. The collectors of forest revenues are the forest guards and they are grossly inadequate. Since their offices are situated in the Local governments, forest revenues are collected at that point. Most cases, they move about from enclaves to the entrance of the reserves, or stay on the road. Furthermore, the crafty nature of the timber contractors and the enclaves made the forest guards/ revenue collectors to patrol the reserves, the enclaves and sometimes stay on strategic roads. Though field accounts are audited regularly in Abia State as obtained in Ondo State (Oluwafemi, 2003). From his study on forest revenue systems in Ondo State, inadequate manpower, absence of proper logistics, lack of training of revenue staff and incompetent forest personnel were identified as key factors leading to low revenue generation (Oluwafemi, 2003). In Abia State, the forests have been excessively exploited over the years without significantly enhancing their growth, stock density, structure and species density. The exploitation is without regard for sustainability as harvest is consistently very much higher than its growth. In a bid to improve the revenue base of the state government, forests have been converted to nonforest uses such as permanent and shifting agriculture, human settlement, residential building, construction of roads and industrial estates. Forest structure and condition had changed making it difficult for it to perform its natural functions of production, protection, and provision of valuable amenities (ABSEED, 2005). Government arbitrarily fixes revenue target due to its well-known pattern of incremental budgeting system, while the revenue collectors have been unable to meet up with the revenue target during the ten years under review. In many states, forest services were forced to aim at revenue targets that are not in tune with either good forest management practices or the interests of the community. Targets are arbitrarily set since they are usually fixed in relation to the preceding year's performance. When a target cannot be met in one year, it is reduced in the following year and vice-versa. For example, in Cross River State, the gross revenue target for 1975/76 was N 698,000, but achievement was only $12.01 \%$, leading to the target being reduced to $\mathrm{N}$ 580,000 (Udo, 1982) in the subsequent year. Though estimated revenue seems to be relatively low (Table 4) compared to that of Ondo State (Oluwafemi, 2003), this is as a result of many factors which include break down of vehicles used by the forest guards to control exploitation and transportation of forest products and inadequate staff strength. Moreover, the uniformed forest staff are not motivated, nor equipped enough to enforce the laws concerning forest exploitation. Most often, forest products are exploited by rural communities bordering the forests without paying the necessary charges for permits to collect the products (FAO, 2001). From the study carried out, it was observed that adequate incentive needed to motivate forest revenue collectors in the Abia State forestry sector is not in place. The Ministry of Environment revenue officers rarely visit administrative zones to get themselves updated on the forest activities. Though there is constant audit of the forest revenue book, lapses exist as a result of failure to monitor and supervise the entire revenue collection activities by the relevant authority. Training and re-training of revenue staff will go a long way in ensuring efficiency in revenue collection. However, such incentive was not in place between the periods under review. Also, unavailability of welfare package has been a problem in forest revenue generation in Abia State. Since most people involved in timber business are recalcitrant and dubious in doing the business, coupled with obvious administrative and management lapses, illegal harvesting of forest products is rampart. Forest guards who also work as revenue collectors go extra mile to enforce law and bring to book those breaking forest laws. These in most cases have landed the forest guards into problems and untold hardship thereby demands government intervention. Though there is no universal model for success, Abia State forestry department's incentive approach has not been successful. Much of the impetus provided by the Abia State forestry department to its revenue staff has been 
through indirect incentives, particularly monthly salary. Such an approach may or may not be successful elsewhere depending on the salary amount (FAO, 2001).

Conclusion: The forest estate of Abia State constitute renewable resources infinite in diversity and potentials. The state government has over the last decade used the forest as a source of revenue to meet developmental needs. Hence, forests are now more unsystematically exploited without restraint. A concerted effort is therefore imperative in order to salvage the forest sector from the onslaught of stakeholders who are interested only in the revenue potential of the sector and greatly scared of the pertinent resource needs.

\section{REFERENCES}

Abia State Planning Commission. (2005). "Abia State Economic Empowerment and Development Strategy (ABSEEDS)." Umuahia: Abia State Planning Commission (2005).

Brown, S; Maserea, O; Sathaye, J (2000). Projectbased activities. In: Watson RT; Noble IR; Bolin B; Ravindranath NH; Dokken DJ (eds.). Land use, land-use change and forestry: A special report of the IPCC, Cambridge, United Kingdom. Cambridge University Press.

Cranford, M; Henderson, IR; Mitchell, AW; Kidney, S; Kanak, DP (2011). Unlocking Forest Bonds: A High-Level Workshop on Innovative Finance for Tropical Forests. In Workshop Report. WWF Forest \& Climate Initiative, Global Canopy Programme and Climate Bonds Initiative (Vol. 249).

Diaw, K; Nnkya, T; Watson, V (2002). Planning Education in Sub-Saharan Africa: Responding to the demands of a changing context. Plan. Pract. Res. 17(3): 337-348.
Etukudo, IG; Akpan-Ebe, IN; Udofia, A; Attah, VI (1994). Elements of Forestry. Usanga and Sons Publishers, Uyo, Nigeria.

Food and Agriculture Organization of the United Nations (2001). The state of food insecurity in the world.

Leuschner, WA (1984). Introduction to forest resource management. John Wiley \& Sons.

Nelson, IU; Jacob, DE (2017). An Assessment of Forest Revenue Generation in Akwa Ibom State, Nigeria. Medi. J. of Bas. Appl. Sci. 1(1): 221-230.

Okafor, JC (1991). Improving Edible Species of Forest Products, Unasylva (FAO).

Okafor, JC (1980). Edible indigenous woody plants in the rural economy of the Nigerian forest zone. For. Eco. Man. 3:45-55.

Oluwafemi, O (2003). Dynamic of Forest Revenue System in Ondo State, submitted to the Department of Forest Resources Management, University of Ibadan.

Rosendal, GK; Andresen, S (2011). Institutional design for improved forest governance through REDD: Lessons from the global environment facility. Ecol. Econ. 70(11): 1908-1915.

Udo, RK (1982). Food production and agricultural development strategies in Nigeria, in: Joint Research Program Series (Japan), No 31, Institute of Developing Economies, Tokyo.

UNFCCC (2008). Investment and financial flows to address climate change: an update. In United Nations Framework Convention on Climate Change Report. 